\title{
ANALIZA POKAZATELJA RENTABILNOSTI POSLOVANJA HOTELSKIH PREDUZEĆA
}

\section{Nikica Radović, Nenad Stanić}

Univerzitet Singidunum, Beograd, Srbija

\begin{abstract}
Apstrakt:
Savremeno poslovanje preduzeća se suočava sa brojnim rizicima, bilo da su u pitanju poslovni ili tržišni rizici. Ukoliko nije razrađeno uspešno upravljanje rizicima, preduzeće može imati ozbiljnih problema sa odvijanjem poslovnih procesa, kao i sa poslovnim rezultatom. Poslovanje hotelskih preduzeća predstavlja homogen i složen sistem koji je pod velikim uticajem poslovnih rizika. Veoma je važno praćenje prodaje smeštajnih kapaciteta tj. popunjenosti kapaciteta hotelskog preduzeća, imajući u vidu da upravo od njih zavisi visina prihoda, a samim tim i rentabilnost poslovanja preduzeća.

U radu će biti dat osvrt na pokazatelje rentabilnosti, kao i rezultati analize pokazatelja rentabilnosti na uzorku hotela sa četiri i pet zvezdica koji posluju u Srbiji za period od 2010. do 2015. godine.
\end{abstract}

Ključne reči:

pokazatelji rentabilnosti, hotel, iskorišćenost kapaciteta.

UVOD

Hotelsko poslovanje u svetskim tokovima predstavlja veoma značajnu privrednu delatnost, imajući u vidu da učestvuje u privrednom razvoju i prihodovanju velikog broja zemalja. Kao sastavni deo industrije turizma jedan je od njenih kapitalnih nosilaca, uzevši u obzir da hoteli predstavljaju najzastupljeniji vid smeštajnih kapaciteta. Poslovanje hotelskog preduzeća je kompleksno i odvija se u raznim poslovnim aktivnostima npr. proizvodni, uslužni, administrativni i poslovi održavanja, a najčešće se odvijaju po sektorima poslovanja - sektor soba, sektor hrane i pića, sektor Spa\&Wellnessa, sektor prodaje i marketinga, sektor poslova administracije, IT sektor, sektor održavanja. Menadžeri u hotelijerstvu su pred stalnim izazovima praćenja i održavanja finansijske sigurnosti i pokazatelja poslovanja kako bi bili u mogućnosti da odgovore izazovima savremenih kretanja u industriji turizma.

Rentabilnost je ekonomsko načelo poslovanja koje se zasniva na poslovnim aktivnostima i to tako da se uz minimum uloženih sredstava ostvari maksimalan profit preduzeća. Prilikom analiziranja pokazatelja rentabilnosti poslovanja predmet istraživanja su: stopa bruto dobitka, stopa poslovnog dobitka, stopa neto dobitka, stopa prinosa na sopstvena sredstva (ROE), stopa prinosa na imovinu (ROA) i stopa prinosa na investicije (ROI) (Ivanišević, 2012). Cilj preduzeća je maksimiziranje dobitka na dugi rok, a cilj praćenja indikatora rentabilnosti je da se sagleda stepen ostvarenja postavljenih ciljeva (Spasić \& Čerović, 2014).

\section{POKAZATELJI RENTABILNOSTI U HOTELSKOM POSLOVANJU}

Ovim radom obuhvaćena je analiza stope prinosa na ukupna sredstva (ROA), stope prinosa na sopstvena sredstva (ROE), stope poslovnog dobitka i stope neto dobitka. Za proračun pokazatelja rentabilnosti korišćeni su podaci dobijenih iz finansijskih izveštaja 
preuzetih sa sajta Agencije za privredne registre (APR) za dvadeset hotelskih preduzeća sa pet i četiri zvezdice, koji posluju u Srbiji, u periodu 2010-2015. godine. Nakon obrade preuzetih podataka dobijeni su pokazatelji kako sledi u tabeli 1 :

Tabela 1. Pokazatelji rentabilnosti analiziranih hotelskih preduzeća za period 2010-2015. godine

\begin{tabular}{ccccccc}
\hline $\begin{array}{c}\text { Poslovna } \\
\text { godina }\end{array}$ & 2010 & 2011 & 2012 & 2013 & 2014 & 2015 \\
\hline ROA & $8,35 \%$ & $3,22 \%$ & $8,53 \%$ & $6,79 \%$ & $4,50 \%$ & $3,54 \%$ \\
\hline ROE & $3,85 \%$ & $3,71 \%$ & $10,67 \%$ & $8,20 \%$ & $3,82 \%$ & $3,17 \%$ \\
\hline $\begin{array}{c}\text { Stopa poslovnog } \\
\text { dobitka }\end{array}$ & $14,80 \%$ & $9,75 \%$ & $12,60 \%$ & $16,15 \%$ & $11,48 \%$ & $11,72 \%$ \\
\hline $\begin{array}{c}\text { Stopa neto } \\
\text { dobitka }\end{array}$ & $5,83 \%$ & $6,20 \%$ & $6,15 \%$ & $8,99 \%$ & $7,45 \%$ & $8,10 \%$ \\
\hline
\end{tabular}

Izvor: Obračun autora

Stopa prinosa na ukupnu imovinu (aktivu) (Return on Assets - ROA) prezentuje sliku o ukupno angažovanim sredstvima preduzeća. Na osnovu prezentovanih vrednosti pokazatelja ROA u tabeli 1 i na slici 1 uočeno je da se javljaju promene u kretanjima vrednosti.

Slika 1. Kretanje ROA

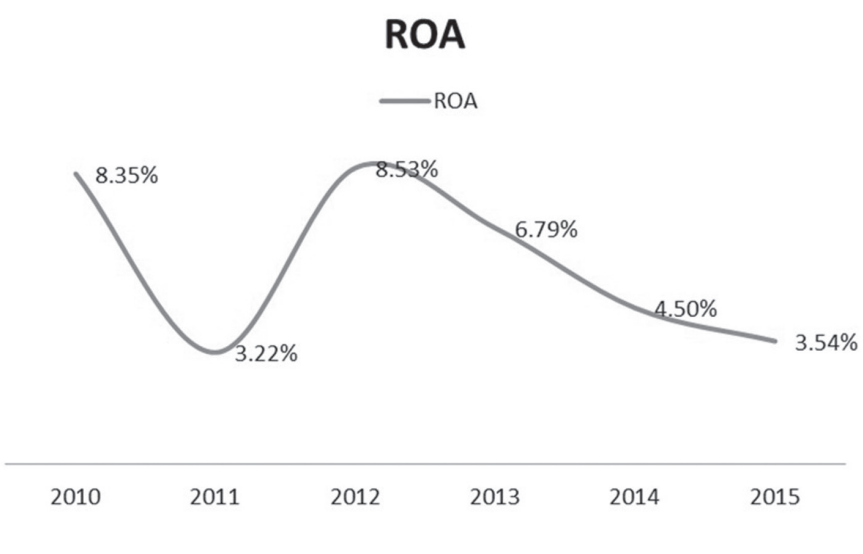

Izvor: Obračun autora

Naime, obračunate vrednosti ROA pokazuju da se na svakih 100 dinara investiranog kapitala u različite oblike imovine u 2010. godini ostvaruje prinos od 8,35 dinara, u 2011. godini prinos opada i iznosi 3,22 dinara, u 2012. godini raste na 8,53 dinara. Potom vrednosti ROA su u konstantnom opadanju, pa se u 2013. godini ostvaruje 6,79 dinara, u 2014. godini 4,50 dinara i u 2015. godini 3,54 dinara. Dakle, u 2011, 2013, 2014. i 2015. godini dolazi do pada vrednosti ROA što ukazuje na smanjenu sposobnost generisanja profita, dok vrednosti za 2010. i 2012. godinu ukazuju na porast sposobnosti preduzeća za generisanje profita. Ovakve vrednosti oslikavaju kolebanja u finansijskoj snazi hotelskih preduzeća, a to je najčešće uslovljeno prezaduženošću hotelskih preduzeća, malim procentom iskorišćenosti kapaciteta, pa se javlja mali ili nedovoljan obim prihoda.

Preduzeća u svom poslovanju imaju različitu strukturu kapitala, vlasničkog i pozajmljenog, pa samim tim i različito učešće obaveza (Malinić et al., 2012). Imajući u vidu da je u 2012. godini najviša stopa pokazatelja zaduženosti javlja se problem nemogućnosti generisanja profita koji se ogleda u padu vrednosti ROA za naredne godine. Cilj poslovanja preduzeća je maksimizacija ROA tj. da sa minimalnim ulaganjima poslovnih sredstava preduzeće ostvari veće poslovne prihode. Maksimiziranje stope prinosa na ukupnu imovinu moguće je kroz dve varijante: povećanjem stope dobitka ili/i povećanjem obrta poslovnih sredstava (Knežević, 2009).

\section{Stopa prinosa na sopstvena sredstva (Return on Equity} - ROE) predstavlja opšti pokazatelj uspešnosti poslovanja preduzeća, imajući u vidu da se ovim pokazateljem prezentuje stopa rasta vlasničkog kapitala. Vrednosti pokazatelja ROE u tabeli 1. i na slici 2. su u trendu pada. U 2011. godini ROE je bio $3,71 \%$ što znači da je na svakih 100 dinara angažovanih sopstvenih sredstava ostvareno 3,71 dinara neto dobitka, dok je u 2012. godini ROE dostigao vrednost od 10,67\%, tj. na svakih 100 dinara angažovanih sopstvenih sredstava ostvareno je 10,67 dinara neto dobitka. Od 2012. godine dolazi do pada vrednosti ROE do 3,17\% u 2015. godini. Pad vrednosti ROE ukazuje na pad u zarađivačkoj sposobnosti preduzeća tj. na nizak stepen iskorišćenosti smeštajnih kapaciteta analiziranih hotelskih preduzeća.

Slika 2. Kretanje ROE

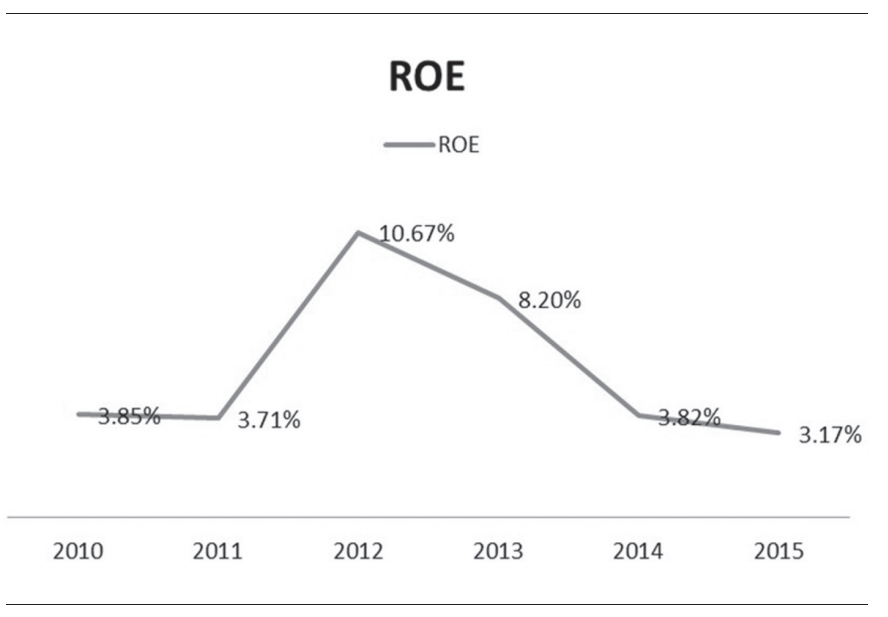

Izvor: Obračun autora

Razlika između stope prinosa na ukupnu imovinu - ROA i kamatne stope koja se plaća na pozajmljena sredstva preusmerava se ka vlasnicima kapitala. Kako visok nivo zaduženosti omogućava privrednom društvu da sa malim iznosima sopstvenih sredstava vrši velike investicije, pomenuta razlika u takvim situacijama može biti velika u odnosu na vlasnički ulog i uzrokovati razlike u odnosu na stope prinosa na 
vlasnički kapital - ROE (Stanišić, 2013). Istovremeno, preduzeće može povećati stopu prinosa na sopstvena sredstva maksimiziranjem stope neto dobitka i/ili maksimiziranjem koeficijenta obrta sopstvenih sredstava kapitala (Barjaktarović et al., 2013).

Stopa poslovnog dobitka pokazuje koliko je učešće poslovnog dobitka u neto prihodima od prodaje.

Slika 3. Kretanje stope poslovnog dobitka

\section{Stopa poslovnog dobitka}

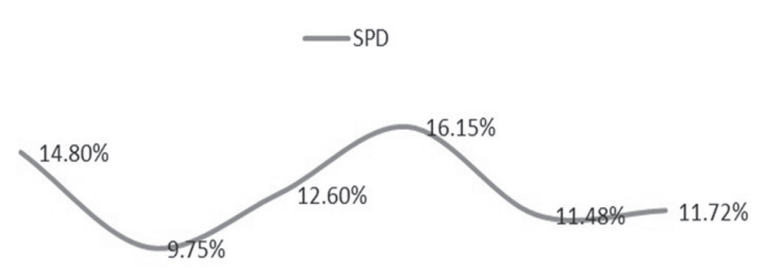

2010

2011

2012

2013

2014

2015

Izvor: Obračun autora

Imajući u vidu prezentovane prosečne vrednosti pokazatelja za analizirana preduzeća jasno je da se javljaju kolebanja u vrednostima poslovnog dobitka (tabela 1 i slika 3 ). $\mathrm{Na}$ osnovu obračunatih vrednosti rezultati ukazuju na to da je učešće poslovnog dobitka u neto prihodima od prodaje u padu za 2011. godinu i iznosi 9,75\%. Preduzeća su u proseku na svakih 100 dinara prihoda u 2010. godini ostvarivala 14,80 dinara dobiti, u 2012. godini 12,60 dinara dobiti, a u 2013. godini 16,15 dinara dobiti. Prema prikazanim rezultatima u 2011. i 2014. godini vrednosti su u blagom padu, dok su u 2015. godini sa tendencijom ponovnog rasta.

Stopa neto dobitka pokazuje koliko je učešće neto dobitka u ukupnim neto prihodima od prodaje i predstavlja rezultat uspešnosti ulaganja sopstvenog kapitala.

Slika 4. Kretanje stope neto dobitka

\section{Stopa neto dobitka}

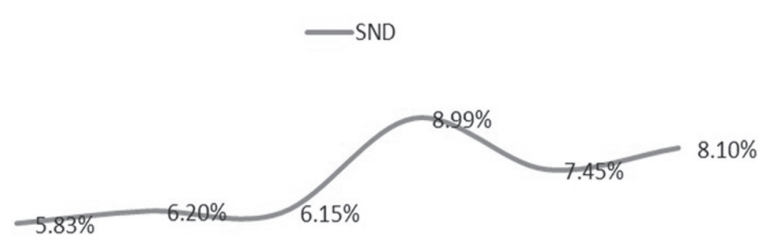

\section{0} 2011 2012
2014

2015

Izvor: Obračun autora

Stopa neto dobitka nema pravolinijski rast, imajući u vidu pad vrednosti u 2012. godini na 6,15\%, sa 6,20\% u odnosu na prethodnu 2011. godinu. Potom se javlja uzlazni trend i stopa neto dobitka ostvaruje vrednost od $8,99 \%$, a u 2014 . godini opet dolazi do pada vrednosti stope na 7,45\%. U 2015. godini dolazi do rasta vrednosti stope neto dobitka na $8,10 \%$. Ako se u poslovanju preduzeća javljaju dugovi nastali zaduživanjem uz visoke kamatne stope, bez obzira na visinu poslovnog dobitka može se javiti mali neto dobitak, pa čak i neto gubitak (Ivanišević, 2012).

\section{ZAKLJUČAK}

Nakon obrade podataka dobijeni su pokazatelji rentabilnosti, a analizom dobijenih vrednosti u tabeli i na slikama uočeno je da su hotelska preduzeća u situaciji stalnih kolebanja vrednosti pokazatelja, imajući u vidu da su pojedina preduzeća $u$ analiziranom periodu, prema dostavljenim finansijskim izveštajima, imala loše poslovne rezultate tj. radili su sa gubitkom. Pretpostavka je da su nepovoljni rezultati posledica: visokih fiksnih troškova koji su specifični za hotelsko poslovanje, prezaduženosti hotelskih preduzeća, ekonomske krize, a malog procenta iskorišćenosti kapaciteta koji sa sobom donosi niske, nedovoljne prihode.

Nasuprot kolebanjima u rezultatima poslovanja analiziranih hotelskih preduzeća interesantno je sagledati podatke nadležnog ministarstva o broju kategorisanih hotela. Naime, prema podacima nadležnog ministarstva u 2008. godini bilo je 242 hotela, u 2012. godini, kategorisano je 298 hotela, u avgustu 2015. godine ima 332 hotela, a u junu 2016. godine u Republici Srbiji ima 347 kategorisanih hotela, garni hotela ili apart hotela od jedne do pet zvezdica (www.mtt.gov.rs). Prema navedenim podacima za osam poslovnih godina ima 95 hotela više. Iako je trend otvaranja hotela u porastu, pokazalo se da je postojeći broj hotela nezadovoljavajući najčešće u vreme odvijanja velikih događaja kada nema dovoljno smeštajnih kapaciteta, a takođe nema dovoljno hotela sa pet zvezdica (trenutno ih je sedam). Kako bi se promenila trenutna situacija u poslovanju hotelskih preduzeća, a u cilju poboljšanja poslovanja i finansijske situacije, kao i povećanja broja hotela, neophodan je rad na izradi poslovnih planova i strategija, kao i prilagođavanje savremenim tendencijama na turističkom tržištu, uz promociju konkurentnih prednosti Srbije kao turističke destinacije.

\section{LITERATURA}

Barjaktarović, L., Jović, Z., \& Milojević, M. (2013). Poslovne finansije. Beograd: Univerzitet Singidunum.

Ivanišević, M. (2012). Poslovne finansije. Beograd: Ekonomski fakultet.

Knežević, G. (2009). Analiza finansijskih izveštaja. Beograd: Univerzitet Singidunum. 
Malinić, D., Milićević, V., \& Stevanović, N. (2012). Upravljačko računovodstvo. Beograd: Ekonomski fakultet.

Ministarstvo trgovine, turizma i telekomunikacija. (2016). Kategorizacija. Preuzeto 16.09.2016. sa http://mtt. gov. rs/sektori/sektor-za-turizam/kategorizacija/
Spasić, V., \& Čerović, S. (2014). Ekonomsko-finansijska analiza poslovanja preduzeća u hotelijerstvu i turizmu. Beograd: Univerzitet Singidunum.

Stanišić, N. (2013). Analiza finansijskih izveštaja: primer Hotel Moskva a.d. Beograd 2012. Preuzeto 12. 06. 2016. sa http:// ssrn. com/abstract $=2332096$

\section{THE ANALYSIS OF PROFITABILITY IN MANAGEMENT OF HOTEL ENTERPRISES}

\section{Abstract:}

Modern mamagement of enterprises abounds in risks, both business and market ones. If an enterprise has not elaborated effective risk management, an enterprise may have serious problems with business processes and business results. Management od hotel enterprises is homogeneous and complex system of business which is heavily influenced by business risk. It is very important to follow sales of accommodation capacities i.e. occupancy of hotel capacity, bearing in mind that the amount of income depends on it, and thus the profitability of the enterprise.

The paper will give an overview of the indicators of profitability, as well as the results of the analysis of indicators of profitability on a sample of hotels operating in Serbia in the period from 2008-2012.

\section{Keywords:}

indicators of profitability, hotel, capacity utilization. 